\title{
The Judiciary Competent to Hear the Problems of Implementation in the Judicial Decisions of the Administrative Courts "Comparative Study Between Egypt and Jordan"
}

\author{
Dr. Ayman Yousef Mutlaq Al-Refo \\ Assistant Professor / Faculty of Law, Middle East University - Jordan
}

DOI: $10.7176 / \mathrm{JLPG} / 89-23$

Publication date:September $30^{\text {th }} 2019$

\section{Introduction}

1.1 The importance of study

The judicial verdict may not be suspended except by the Court of Appeal. If the verdict is issued by the highest judicial body such as the Supreme Administrative Court in Jordan or in Egypt, it shall be enforceable. The sovereignty of the State whose entity and sovereignty derives from the judicial authority that adjudicates disputes shall be exercised by the State. This is confirmed by the text of article 50 of the Egyptian Council of State Law No. 47 of 1972, which stipulates that "Appeal before the Supreme Administrative Courts shall not suspend the execution of the contested judgment unless the Appeals Examination Chamber has ordered otherwise. Judgments issued by administrative courts shall be suspended unless the court orders otherwise. In the same vein, Article 28 of the Jordanian Administrative Judiciary Law No. 27 of 2014 stipulates that "Appeal before the Supreme Administrative Court shall not suspend the execution of the contested judgment unless the court orders otherwise that).

This study dealt with a very important topic related to the judicial authority competent to consider the problems of implementing the judgments issued against the administration in case the administration refuses to implement them, in the light of the inability of the administrative judge to interfere in the work of the administration pursuant to the principle of separation of powers that prevents administrative interference in The work of the administration or its replacement.

There is no doubt that the administration's failure to implement judicial rulings is a violation of this principle and constitutes a prejudice to the power of the judiciary as a constitutional institution, as well as a violation of the democratic approach of States, as the amount of respect for states is determined by the extent of respect for the judiciary. Moreover, the administration's failure to implement the judgments constitutes a dangerous precedent that destroys the principle of legality so that it loses its historical and sovereign value unless the administration respects its content, elements and sources.

1.2 The limits of the study

The limits of the study in this research are to determine the court competent to hear these problems and the extent of the limits of the jurisdiction of the administrative judiciary in general to consider the problems of implementation in both Jordan and Egypt and to remove the confusion between the problems in implementation and suspension of execution from the Court of Appeal exploring the position of legislation and jurisprudence and administrative judiciary in both countries in an analytical study And in-depth following the descriptive, analytical and applied approach. However, it will be beyond the limits of this study to go into the justification for the failure of the administration to implement and the reasons for the abstinence and responsibility resulting from this abstinence, civil and administrative, although we will only refer to it as a preliminary introduction for the purpose of understanding the subject of this study in all its aspects.

\section{Cases of refusal of the administration to implement the judgments}

The administration may take a number of cases in order to evade execution, such as delays in the execution of its cancellation verdict, lack of execution in the verdict, refraining from execution by issuing an individual or organizational administrative decision or by explicit or implicit refusal to execute the judicial verdic ${ }^{1}$.

\section{The justification for the administration's failure to implement the provisions}

Many jurisprudence unanimously ${ }^{2}$ concludes that the administration is hiding behind the principle of legality in an attempt to create legal and other realistic reasons to justify the way of refraining from executing the

\footnotetext{
${ }^{1}$ Shatnawi, F. (2016), Administrative Judgments Issued against Administration and Problems of Execution. Journal of the University of Jordan-Studies of Sharia and Law Sciences, 43, Appendix1

${ }^{2}$ Dr. Faisal Al-Shatnawi - previous reference - pp. 9-10
} 
judgments issued by annulment. It may create difficulties for implementation that would make it difficult to prove by the individual when trying to highlight the administration's deviation in its discretion and may invoke reasons related to public security and social peace.

\section{Problems in implementing sentences}

Temporary executive disputes or implementation problems ${ }^{1}$. These are those related to the progress of the implementation procedures and aim at obstructing its procedures, by including allegations, if true, that would have an effect on the implementation, leading to either a temporary suspension or continuation after the suspension, and may reach the degree of influence to make it either true or invalid implementation.

$\mathrm{Or}^{2}$ is "temporal dispute is the one that arises on the occasion of forced implementation and is focused on taking or not taking action of its actions without being exposed to the essence of the executive bond (problematic in its narrow sense).

$\mathrm{Or}^{3}$ that is the case brought to the judiciary requesting a decision to temporarily adjudicate the issue of the dispute. This means that the forms of execution are those, which are about the legal obstacles related to the conditions that must be met to take the measures of compulsory execution. Suspension, continuation, nonapplication, or limitation of scope or judgment in respect of any exhibitor related to such execution

By looking at many definitions in this regard, we see that the temporal problems in implementation is one of the forms of disputes that arise on the occasion of the implementation of judicial rulings, because the issuance of a judicial ruling even if it has a valid order - does not necessarily mean the end of the dispute in which it was issued. In all its aspects, but everything that means the end of the first stage of the legal litigation, the litigation of the judgment and may be followed by another litigation is the litigation of the implementation, as it may interfere with the functioning of the natural rule in order to reach its natural purpose - namely, its implementation - some legal and other Qan The intention of affecting the most important of these are symptoms of implementation disputes that are problematic one of its forms.

According to Egyptian ${ }^{4}$ jurisprudence, the temporal problem in implementation is aimed at providing temporary protection to those who resort to it, which is to suspend the execution if the form is implemented against him or others or if it is temporarily continued if the form is the applicant. Because of the slow pace and complexity of the procedures is not consistent with the procedures of implementation and characterized by speed, so the litigant usually prefer to resort to the path of problem.

\section{The court competent to hear the problems of implementation in administrative judicial decisions and the limits of this jurisdiction}

To determine the competent court and the limits of this jurisdiction, it is necessary to address the position of legislation in terms of jurisprudence and administrative judiciary in both countries Egypt and Jordan because of this question raised by the jurisprudence and judicial difference in each country and because of the legislative deficiency to determine this jurisdiction, which was the legislation governing the administrative judiciary in both countries.

\subsection{The position of legislation, jurisprudence and the judiciary in Egypt}

The researcher in this part of the research will speak in depth and analysis of the position of jurisprudence and the judiciary in Egypt of the difference on the competent judiciary and the position of the Egyptian administrative judiciary of the difference in determining the competent court between the past and present.

The successive laws regulating the Egyptian State Council, the latest of which is the current Law of the State Council No. 47 of 1972, did not include a provision that authorizes the courts of the Council of State to consider the implementation problems related to the judgments issued by its courts.

Some of the ${ }^{5}$ jurisprudence gave rise to several reasons that led the administrative judiciary at first to determine its lack of competence to consider these problems. Appealed by the Court of Appeal. This confusion may be due to the stipulations of Article 50 of the Egyptian State Council Law. This provision led to the end of the Administrative Judicial Court to the lack of jurisdiction to consider these problems in addition to that the

\footnotetext{
${ }^{1}$ The Jordanian legislator used the terms - Article 19 of the Jordanian Implementation Law No. 25 of 2007 and its amendments to the amended Law No. 29 of 2017 - both of which refer to the same meaning.

${ }^{2}$ Samamah, K., R. (2015), the provisions of temporal disputes in the Jordanian law of implementation "applied analytical study". Journal of the balance of Islamic and legal studies, II, Number 1

${ }^{3}$ Lawyer Abul-Ela, Marwa, (2019) Discussing the organization of the implementation problems in the provisions of the Council of State in accordance with the Court of Cassation. [Online] Available:

${ }^{4}$ Ahmed, T. A. (1996). Temporal Problems in the Implementation of Administrative Provisions. Dar Al-Nahda Al-Arabiya

${ }^{5}$ Dr.. Hosni Abdel Wahed - the implementation of administrative provisions - p. 108 - and see d. Mohammed Kamal al-Din Munir - his letter to the administrative urgent matters 1988 - p 348 - and see Dr. Mohammed Maher Abu al-Ainain - the batch within the scope of common law - Book II - Dar Arab Renaissance - 2002 - where he presented his sovereignty of the provisions as a rule 578 for the year $23 \mathrm{~s}$ session $181 /$ 1972- Q26- p. 36 as well as case No. 271 for the year 27 BC - hearing 5/4 1973 - Q 27- p. 205 in the author p. 1036 and beyond
} 
failure to provide in the law of the Council of State to the competent court of these problems must refer to the original in the jurisdiction of the execution judge in ordinary courts, which led the legislator to rule out the idea of Judgments of the Administrative Court of Justice in order to suspend their execution

According to the jurisprudence ${ }^{1}$ direction that the Administrative Court and then the Supreme Administrative Court has been aware of the differences between the problems of implementation on the one hand and the suspension of execution by the Court of Appeal on the other hand, on the basis of the difference in the dispute relating to the implementation of a judgment from the reasons for challenging this judgment and Implementation disputes relate primarily to material or legal obstacles that arise after the judgment is rendered and make its execution significantly affect the interests of others or make it impossible to complete. Whereas the reasons for challenging the court's judgment are based on legal grounds upon which the contested judgment is based, the appellant considers these reasons to be incorrect without considering the execution of this judgment. Hence, the Supreme Administrative Court concluded that the problems of implementation of the judgment are disputes that have nothing to do with the origin of the fixed right and are not an appeal against it, but are related to the same execution and whether it is true or false is permissible or not.

Accordingly, the administrative judiciary has settled on its competence to consider the problems of implementation presented in the judgments issued by it, in accordance with the provisions of Article 3 of the Articles of the Law of the Council of State No. 47 of 1972, which states that Provided that a law shall be issued for the procedures of the judicial department.

Through analytical reading of these jurisprudential opinions and judicial rulings, and although it gave the administrative judiciary jurisdiction to consider the implementation problems related to its provisions, the researcher believes that it did not specify the exact court competent to consider these problems and that the researcher was unable to determine the limits of the jurisdiction of the administrative judiciary in general.

Perhaps what came one of ${ }^{2}$ the jurisprudence has answered the researcher's questions in this area, where he argued that the jurisdiction of disputes of implementation within the administrative judiciary will always be the court of the first degree, which falls into the original dispute in its jurisdiction even if it comes to the implementation of a judgment issued by a court of second degree because the problems In the case of execution or dispute therein, it is merely a new case that should be subject to the general rules of litigation that require that the case be filed for the first time before the court of first instance.

The same trend adds that since the stage of implementation of the judgment, whatever the article in which it was issued, is completely independent from the previous dispute procedures in this implementation, it has nothing to do with the established right to rule and is not an appeal against it, but it is related to the same execution and whether it is true or false. Thus, the jurisdiction of the court has the general jurisdiction in administrative disputes even if it comes to the implementation of a ruling by a higher administrative court because the latter has a specific jurisdiction as well as that after the issuance of the judgment no longer dispute the administrative responsibility for the invalid decision or the implementation of the administrative contract The Court of Justice of Ada $\mathrm{J}$ is always competent court disputes in the implementation of administrative provisions within the jurisdiction of the administrative judiciary originally as a general jurisdiction court. This view is supported by another jurisprudential trend: ${ }^{3} \mathrm{He}$ considers that the right to decide on the problems of the implementation of administrative provisions that fall within the jurisdiction of the Council of State is convened for the court that issued the verdict, because the disputes of implementation in general, although an independent stage of the previous procedures start after obtaining the executive deed and related to the same implementation and whether it is true or false It is permissible or not, but it is not considered to be relevant to the original dispute, since such disputes are often closely related to the same dispute in which the judgment was made or established. The problem of execution is not a new litigation, but it is a matter of urgency arising from the original dispute. Moreover, the jurisdiction of the court that issued the judgment to consider the execution of its judgment is not unusual in the laws of pleadings. The current civil and commercial pleadings have had jurisdiction over the problems of execution held by the summary judge while the court that issued the judgment was competent to hear substantive disputes of execution.

The researcher for his part supports the conclusion of the jurisprudential trend in the reasons mentioned by the jurisdiction to be held by the Administrative Court of Justice, but believes that this situation is not right without legislative intervention or the principle of the Supreme Administrative Court, because without the existence of this requirement or that can not say the jurisdiction of the Court of Justice This jurisprudential trend is ${ }^{4}$ another trend that emphasized the need for legislative intervention or the existence of a stable principle from the Supreme Administrative Court. This trend presented what confirms his view of what was issued by the Supreme Court. In one of its judgments, the courts of the Council of State are exclusively competent to execute

${ }^{1}$ Dr. Mohammed Kamal al-Din Munir - his message - previous reference - p. 354 and beyond

${ }^{2}$ Dr. Hosni Abdel Wahed - his message - previous reference - p. 109

${ }^{3}$ Dr.. Mohammed Kamal al-Din Munir - his letter - previous reference - p. 369

${ }^{4}$ Dr. Mohammed Maher Abu Al-Enain - Defenses in the scope of the common law - previous reference - p. 7/1988 
disputes relating to the administrative judgments of each court within the limits of its jurisdiction. Branch Judge.

With regard to the question raised by the researcher on the limits of the jurisdiction of the courts of the State Council to consider the problems of implementation, the jurisprudence ${ }^{1}$ went to say that the general rule that what falls within the jurisdiction of the courts of the State Council, these courts are competent to consider the problems related to the implementation of judgments issued.

However, due to historical considerations regarding the development of the French Council of State and the prevailing principle that the ordinary judiciary is the protector of private property, the jurisprudence of the pleadings has established that the execution judge of the ordinary courts is competent to adjudicate in all administrative and other disputes as long as such execution affects possession or Ownership or any related right on the basis that disputes of execution are disputes about the tapes that must be available to take action on money.

This trend referred to the ruling of the Supreme Administrative Court, which stated that "although the original judge is limited by the jurisdiction of his jurisdiction, it is established that the judge of execution as a branch of the judicial body having general jurisdiction to hear all disputes relating to money has the This does not affect in any way the rules governing the competence of the different judicial bodies, because the problems of the execution of the verdicts are disputes that have nothing to do with the origin of the fixed right and are not an appeal against it, but they are related to the same execution and whether it is true. As mentioned in the jurisprudence of the Court of Cassation confirming what the Supreme Administrative Court has stated in the judgment of the Court of Cassation, "that the ordinary judiciary does not have jurisdiction to consider the dispute in the implementation of the administrative provisions even if the dispute is related to money if it is built It is one of the procedural or substantive matters in which the administrative judiciary is unique in its consideration without the ordinary judiciary.

This view also supported another ${ }^{2}$ jurisprudential trend, which excluded the problems of implementation related to the implementation of money from the jurisdiction of the administrative judiciary.

He objected to the ${ }^{3}$ jurisprudence of all this, where he believes that there is no basis to take out the cases in which the administrative judgment disputed in the implementation of the money from the jurisdiction of the courts of the State Council and the argument of this trend that the French ideas in this regard does not bind ordinary Egyptian courts or courts of the State Council that these ideas It was the result of historical developments that can not be relied upon in their place and time. On the other hand, the fact that the disputes relating to the implementation of the money on the jurisdiction of the administrative judiciary is not justified unless there is a provision to determine it. Regular and wiped out Of the State Council in this regard.

The researcher, in turn, tends to this view and advocates that the issue of competence is one issue is indivisible and this calls for the opinion of the researcher careful legislative regulation clarifies the competence to consider disputes of temporal implementation, leaving no room for contradiction and conflict between the State Council and the ordinary judiciary.

Finally, the Egyptian Constitution of 2014, as amended in 2019, resolved this issue in terms of competence in view of the problems of implementation of administrative judicial rulings issued by the courts of the Egyptian Council of State in Article 190, which states that "The State Council is an independent judicial body, exclusively competent to settle administrative disputes." It also deals with disciplinary challenges and appeals. It issues advisory opinions on the legal issues of the parties specified by law, reviewing draft laws and decisions of legislative nature referred to it, and reviewing draft contracts that it determines and determines. The State or one of the public bodies shall be a party to it, and the other functions shall be determined by law.

\subsection{The position of legislation, jurisprudence and the judiciary in Jordan}

Jordanian legislation has been absolutely free, whether related to the constitutional rules represented by the Jordanian Constitution of 1952 as amended, as well as the laws of the Supreme Court of Justice, which were abolished and represented by its temporary law No. 11 of 1989 and its law No. 12 of 1992 and the current law, the Administrative Justice Law No. 27 of 2014 from any Texts specifying the court competent to hear the implementation problems related to administrative judicial decisions.

In light of this legislative vacuum, jurisprudence and the judiciary confronted finding logical solutions, despite the limited number of spokespersons and the scarcity of judicial rulings in determining the jurisdiction. One of their attempts was to provide the administrative judge with effective means to ensure the implementation of the cancellation rulings. Managing a judgment to cancel the negative decision issued to refrain from implementing the cancellation judgment and holding the administration and its employees to civil and criminal

${ }^{1}$ Dr. Hosni Abdel Wahed - previous reference - p. 120 where the decision of the Supreme Administrative Court in case No. 513 of 16 BC hearing 28/4/1974 and the Court of Cassation hearing 1/2/1973

-i as well as his support opinion Dr. Fathi Wal -p 360 and beyond -previous reference -his message -Dr. Mohamed Kamal El Din Mounir 2 forced implementation - 1988 - p 681

${ }^{3}$ Dr. Mohammed Abul-Enein - previous reference - p. 1040 
responsibility for disrupting the implementation of the cancellation provisions ${ }^{1}$.

According to the ${ }^{2}$ jurisprudence, the position of the Supreme Court of Justice, which was repealed by the current Administrative Judiciary Law, which established two degrees of litigation, namely the Administrative Court and the Supreme Administrative Court, was reluctant between accepting the appeal of decisions to refrain from implementing the judgments issued by the administration and not accepting appeals against these decisions. And declaration of non-jurisdiction.

The researcher supports this trend, as the result of the survey of ${ }^{3}$ judgments issued by the Administrative Court shows that there is no confirmation of the stability of the court on a specific and unified approach.

With regard to the jurisdiction of the Administrative Court in view of the problems of implementation relating to administrative judicial rulings, he sees a jurisprudential direction that the legislator has entrusted to the abolitionist (i.e. the Administrative Court). The law requires the legislator to establish enforcement departments under the abolition court (administrative court) or to provide for the referral of the execution of administrative judicial decisions to the formed enforcement departments of the ordinary courts of justice and give them the same jurisdiction in view of the problems of their implementation. The provisions of what is divided by disputes. He justified his view that giving this cancellation the power to hear the disputes of execution around his decision makes him a biased judgment of his decision to cancel and this in his view this trend in violation of the principle of impartiality of the judge.

The researcher opposes this view, since there is no legislative text that gave the abolitionist the power to look into the problems of the implementation of administrative judicial rulings. On the one hand, the researcher does not support referring these disputes to the enforcement departments related to the ordinary judiciary. There may be problems in its implementation exclusively in administrative disputes and the branches and related to them.

As for the position of the Supreme Court of Justice (Administrative Court), and through an analytical study of the provisions of the judgments, we find that it distanced itself from the consideration of the implementation problems related to the judicial rulings issued by them and that the dispute is a human rights dispute that falls within the jurisdiction of the administrative judiciary. The plaintiffs contest what he called the refusal of the plaintiff against them to implement the decision of the Supreme Court of Justice, the case warrants a response in this regard because the High Court of Justice does not have the power to oblige the administration to implement the decisions issued by them and that the dispute about the implementation or not falls within the jurisdiction of the regular courts ${ }^{4}$.

In the opinion of the researcher, the conduct of the administrative judiciary in Jordan about the judgments issued by the Supreme Court of Justice and did not find anything that contradicts them or turns from them in the judiciary of the administrative court on this issue is contrary to the logic of justice and inspires a loss of confidence and insecurity in the principle of the rule of law.

Perhaps the researcher has found in the text of Article 34, paragraph (b), which states that "the rulings of the Supreme Administrative Court and the decisions of the peremptory administrative court must be implemented in the manner in which they are issued. If the judgment includes the cancellation of the administrative decision in question, all legal and administrative actions and actions taken under this decision as of the date of the issuance of this resolution, "what guarantees the implementation of the resolution, even if it carries some reassurance, but the guarantees in this regard remain insufficient. This means that the reasons for the cancellation rule dictate to the administration its rights and obligations to implement the cancellation provision, especially as the implementation of the cancellation rule includes the reasons in a detailed way to show the administration what to take so as not to violate the law.

\section{Conclusion}

\subsection{Results}

- The study concluded that the court competent to hear the problems of the implementation of administrative judgments issued by the Egyptian State Council is the jurisdiction of the Court of Administrative Justice as settled by the Egyptian judiciary and advocated by Egyptian jurisprudence.

- Judgments issued by the administrative judiciary may not be suspended except by appeal.

- The disputes of execution may be either substantive or temporary disputes in which the judgment requests a temporary measure that does not prejudice the origin of the right, whereas substantive disputes may

\footnotetext{
${ }^{1}$ Dr.. Nawaf Kanaan - Research entitled "Principles Governing the Execution of Abolition Provisions in the High Court of Justice" Journal of Law, Publications of the Scientific Research Council, Kuwait University, Kuwait, Issue (4) December 25, 2001, pp. 284-286

${ }^{2}$ Dr. Faisal Shatnawi - his research - previous reference - p. 18 onwards, where he referred to the contradictory rulings of the Supreme Court of Justice, the first sentence No. 169/84 - Journal of the Jordanian Bar Association for 1985 - p. 1424 and the second judgment No. 54/86 Journal of the Jordanian Bar Association - for the year 1987 - p. 861 For more details see this paper

${ }^{3}$ Dr. Faisal Shatnawi - research - previous reference - p. 19 and beyond

${ }^{4}$ Journal of the Jordanian Bar Association - Issue No. 6 of 1998 - p. 1789
} 
render the execution of the judgment inadmissible.

- The competent authority to deal with the problems of the implementation of administrative judgments in Jordan is still under the jurisdiction of the ordinary judiciary and its enforcement departments.

- The Jordanian legislator gave the administration against which the judgment issued for the abolition of the execution of these provisions, contrary to the civil and penal provisions that are competent to implement them without judicial execution.

- There is no role for the abolitionist judge on the extent of his authority to intervene to ensure and ensure the implementation of the abolition provisions in Jordan.

\subsection{Study recommendation}

- The study recommends the amendment of the current law of the Egyptian Council of State to fill the legislative vacuum by stipulating that the jurisdiction to deal with the problems of implementation of administrative disputes should be the jurisdiction of the Administrative Court, as this provision is in response to the Egyptian Constitutional Legislator who made this jurisdiction to the courts of the Egyptian Council of State.

- The study recommends that the Egyptian Court of Administrative Justice be the owner of the disputes in the problems of the implementation of judicial rulings as a single unit, whether the dispute is on the money or otherwise.

- The study recommends that the Jordanian legislator should stipulate in the Administrative Judicial Law, through its amendment, the jurisdiction of the Administrative Court to hear the administrative dispute concerning the problems of the implementation of judicial decisions issued by it or by the Supreme Administrative Court.

- The study recommends that the Jordanian legislator should provide for the establishment of legislative circles for implementation within the administrative judicial system of the Administrative Court.

- The study recommends the necessity of issuing a judicial principle to be settled by the Jordanian Supreme Administrative Court.

- The Jordanian Constitution should include a provision that gives the administrative judiciary the right to consider administrative disputes related to implementation, as in the Egyptian Constitution of 2014.

\section{References}

\section{First: Legislation}

The Egyptian Constitution of 2014 as amended

The amended Jordanian Constitution of 1952

The Egyptian State Council Law No. 47 of 1972 as amended

The Jordanian Administrative Judiciary Law No. 27 of 2014

Law of the Supreme Court of Justice, repealed No. 12 of 1992

The Provisional High Court of Justice Act No. 11 of 1992 was repealed

The Jordanian Implementation Law No. 25 of 2007 as amended

\section{Second: Public works}

Ahmed, T. A. (1996). Temporal Problems in the Implementation of Administrative Provisions. Dar Al-Nahda AlArabiya

Wahed, H. A. (no year). Implementation of administrative provisions. Publisher \& country

Mounir, M. K. (1988). His mission to spend urgent administrative matters. Publisher \& country

Dr. Mohammed Maher Abu al-Enein, M. M. (2002). Defenses within the scope of public law. (2 ${ }^{\text {nd }}$ ed.). Dar AlNahda Arab

Wali, F. (1988). Forced implementation. Publisher \& country

\section{Third: Published Researches}

Shatnawi, F. (2016), Administrative Judgments Issued against Administration and Problems of Execution. Journal of the University of Jordan-Studies of Sharia and Law Sciences, 43, Appendix 1

Samamah, K., R. (2015), the provisions of temporal disputes in the Jordanian law of implementation "applied analytical study". Journal of the balance of Islamic and legal studies, II, Number 1

Kanaan, N. (2001), Principles Governing the Execution of Abolition Provisions in the High Court of Justice. Journal of Law, Publications of the Scientific Research Council, Kuwait University, Kuwait Issue 4

\section{Fourth: electronic references}

Lawyer Abul-Ela, Marwa, (2019) Discussing the organization of the implementation problems in the provisions of the Council of State in accordance with the Court of Cassation. [Online] Available: https://www.mohamah.net/law/\%d8\%aa\%d $\% \% 86 \% d 8 \%$ b8\%d9\%8a $\% d 9 \% 85$ -

\%d8\%a7\%d8\%b4\%d9\%83\%d8\%a7\%d9\%84\%d8\%a7\%d8\%aa- 
\%d8\%a7\%d9\%84\%d8\%aa\%d9\%86\%d9\%81\%d9\%8a\%d8\%b0-\%d9\%81\%d9\%8a-

\%d8\%a3\%d8\%ad\%d9\%83\%d8\%a7\%d9\%85-\%d9\%85\%d8\%ac\%d9\%84\%d8\%b3-\%d8\%a7\%d9\%84 (2019)

Journal of the Jordanian Bar Association 